\section{Response to: 'IL-23 expression and activation of autophagy in synovium and PBMCs of HLA-B27 positive patients with ankylosing spondylitis' by Neerinckx et al.}

We read with interest the study by Neerinckx et $a l^{1}$ addressing the expression of interleukin (IL)-23p19 and of autophagy genes in the synovium and in the peripheral blood mononuclear cells of patients with ankylosing spondylitis (AS). Differently from our observation in the gut, ${ }^{2}$ the authors failed to demonstrate any significant increase by RT-PCR in the expression of synovium autophagy-related genes (ATG16L1, IRGM, MAP1LC3A, ATG5, HSPA8 and HSP90AA1) together with no significant overexpression of IL-23p19 compared with disease and healthy controls.

We have previously demonstrated by immunohistochemistry that in the gut of AS, Paneth cells (PC), specialised epithelial cells located at the bottom of intestinal crypts, highly express IL-23p19. ${ }^{3}$ Subsequent studies have demonstrated the role of the autophagy related ATG16L1 gene, a genetic risk factor for Crohn's disease, in causing PC dysfunction ${ }^{4}$ and the important interconnection between PC and autophagy in determining the pathogenesis of murine Crohn's disease. ${ }^{5}$ Starting from these findings, we studied the expression of autophagy in the gut of patients with AS. We demonstrated a significant upregulation of the genes involved in the autophagy pathway in the gut of patients with AS by RT-PCR and confirmed autophagy activation in infiltrating mononuclear cells and epithelial cells resembling PCs. ${ }^{2}$ Interestingly, modulation of autophagy results in a significant modulation of the expression of IL-23p19 in isolated lamina propria mononuclear cells of patients and controls. ${ }^{2}$ Autophagy has been demonstrated to play an important role in the innate immune response against intestinal bacteria and its expression seems to be potentially modulated by specific gut microbiota. ${ }^{7-9}$ The presence of an active bacterial stimulation of the innate immune system in patients with AS is indirectly suggested by the activation of PC in producing their antimicrobial products (lysozyme, phospholipase A2 and defen$\sin 5) .{ }^{10}$ In this scenario, the activation of autophagy genes in the gut of patients with AS and its absence in the synovial samples and in the peripheral blood of patients with AS, is not surprising in our opinion.

Conversely, the absence of any significant increase of IL-23p19 expression in the synovial samples of patients with AS observed by Neerinckx et al appears to be surprising. ${ }^{1}$ IL-23p19 has been, in fact, demonstrated by immunohistochemistry to be overexpressed in the inflamed tissues of patients with AS (gut and zygapophysial joints). ${ }^{31}$ Since RT-PCR results need to be confirmed by protein demonstration, immunohistochemistry should also be performed in order to confirm this interesting observation. We, however, agree with Neerinckx et $a l^{1}$ in thinking that IL-23p19 might play a tissue-specific role (in the gut and/or in the lymph node), specifically priming the subset of IL-23-responsive proinflammatory cells.

\section{Francesco Ciccia, Riccardo Alessandro, Giovanni Triolo}

University of Palermo, Palermo, Italy

Correspondence to Dr Francesco Ciccia, University of Palermo, Palermo 90127, Italy; francescociccia@tiscali.it

\section{Competing interests None.}

Provenance and peer review Commissioned; internally peer reviewed.

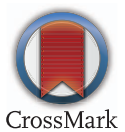

To cite Ciccia F, Alessandro R, Triolo G. Ann Rheum Dis 2014;73:e69.

Received 1 August 2014

Accepted 2 August 2014

Published Online First 20 August 2014

\section{(5) Linked}

http://dx.doi.org/10.1136/annrheumdis-2014-206277

Ann Rheum Dis 2014;73:e69. doi:10.1136/annrheumdis-2014-206346

\section{REFERENCES}

1 Neerinckx B, Carter S, Lories R. IL-23 expression and activation of autophagy in synovium and PBMCs of HLA-B27 positive patients with ankylosing spondylitis. Response to: 'Evidence that autophagy, but not the unfolded protein response, regulates the expression of IL-23 in the gut of patients with ankylosing spondylitis and subclinical gut inflammation' by Ciccia et al. Ann Rheum Dis 2014;73:e68.

2 Ciccia F, Accardo-Palumbo A, Rizzo A, et al. Evidence that autophagy, but not the unfolded protein response, regulates the expression of IL-23 in the gut of patients with ankylosing spondylitis and subclinical gut inflammation. Ann Rheum Dis 2014:73:1566-74.

3 Ciccia F, Bombardieri M, Principato A, et al. Overexpression of interleukin-23, but not interleukin-17, as an immunologic signature of subclinical intestinal inflammation in ankylosing spondylitis. Arthritis Rheum 2009:60:955-65.

4 Cadwell K, Liu JY, Brown SL, et al. A key role for autophagy and the autophagy gene Atg16l1 in mouse and human intestinal Paneth cells. Nature 2008:456:259-63.

5 Adolph TE, Tomczak MF, Niederreiter $L$, et al. Paneth cells as a site of origin for intestinal inflammation. Nature 2013;503:272-6.

6 Peral de Castro C, Jones SA, Ní Cheallaigh C, et al. Autophagy regulates IL-23 secretion and innate $T$ cell responses through effects on IL-1 secretion. J Immunol 2012:189:4144-53.

7 Yano T, Kurata S. Induction of autophagy via innate bacterial recognition. Autophagy 2008;4:958-60.

8 Lu C, Chen J, Xu HG, et al. MIR106B and MIR93 prevent removal of bacteria from epithelial cells by disrupting ATG16L1-mediated autophagy. Gastroenterology 2014;146:188-99.

9 Nguyen HT, Dalmasso G, Müller $S$, et al. Crohn's disease-associated adherent invasive Escherichia coli modulate levels of microRNAs in intestinal epithelial cells to reduce autophagy. Gastroenterology 2014;146:508-19.

10 Ciccia F, Bombardieri M, Rizzo A, et al. Over-expression of paneth cell-derived anti-microbial peptides in the gut of patients with ankylosing spondylitis and subclinical intestinal inflammation. Rheumatology (Oxford) 2010;49:2076-83.

11 Appel H, Maier R, Bleil J, et al. In situ analysis of interleukin-23- and interleukin-12-positive cells in the spine of patients with ankylosing spondylitis. Arthritis Rheum 2013:65:1522-9. 
$\triangle \mathrm{R}$ Response to: 'IL-23 expression and activation of autophagy in synovium and PBMCs of HLA-B27 positive patients with ankylosing spondylitis' by Neerinckx et al.

Francesco Ciccia, Riccardo Alessandro and Giovanni Triolo

Ann Rheum Dis 2014 73: e69 originally published online August 20, 2014 doi: 10.1136/annrheumdis-2014-206346

Updated information and services can be found at:

http://ard.bmj.com/content/73/11/e69

\begin{abstract}
These include:
References This article cites 10 articles, 3 of which you can access for free at: http://ard.bmj.com/content/73/11/e69\#BIBL

Email alerting service

Receive free email alerts when new articles cite this article. Sign up in the box at the top right corner of the online article.
\end{abstract}

\title{
Notes
}

To request permissions go to:

http://group.bmj.com/group/rights-licensing/permissions

To order reprints go to:

http://journals.bmj.com/cgi/reprintform

To subscribe to BMJ go to:

http://group.bmj.com/subscribe/ 